\title{
The labor market in gerontological nursing in Brazil
}

\author{
O mercado de trabalho em enfermagem gerontológica no Brasil \\ El mercado de trabajo en enfermería gerontológica en Brasil
}

\author{
Denise Faucz Kletemberg ' \\ ORCID: 0000-0001-7289-7900 \\ Maria Itayra Padilha" \\ ORCID: 0000-0001-9695-640X \\ Isabel Alves Maliska " \\ ORCID: 0000-0002-6407-6624 \\ Mariana Vieira Villarinho" \\ ORCID: 0000-0002-7706-3689 \\ Roberta Costa" \\ ORCID: 0000-0001-6816-2047
}

'Universidade Positivo. Curitiba, Paraná, Brazil. "Universidade Federal de Santa Catarina. Florianópolis, Santa Catarina, Brasil

How to cite this article: Kletemberg DF, Padilha MI, Maliska IA, Villarinho MV,

Costa R. The labor market in gerontological nursing in Brazil. Rev Bras Enferm. 2019;72(Suppl 2):97-103. doi: http://dx.doi.org/10.1590/0034-7167-2018-0178

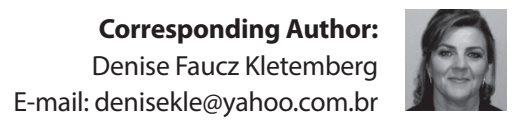

Submission: 03-26-2018 Approval: 11-17-2018

\begin{abstract}
Objective: to analyze the development of the labor market in Gerontological Nursing in Brazil, between 1970 and 1996. Method: a descriptive-qualitative study with a historical approach that uses the oral history of 14 research nurses working in the historical period, based on the ideas of Eliot Freidson. Results: Nursing overcame barriers to change the care practices to elderly people in the period described, considering the lack of a specific labor market; the need for theoretical knowledge for Gerontology care; the scarcity of research and researchers in the field; the emergence of caregivers for elderly people; the construction of multidisciplinarity and the transformation of institutions for a long-term stay. Final considerations: the expansion of the labor market at the time was grounded on advances on the production of knowledge of the aging process, supported by the demographic transition, that determined the increase in the demand by elderly people for health services and the enactment of specific laws protecting this population. Descriptors: History of Nursing; Geriatric Nursing; Elderly People; Labor Market; Geriatrics.
\end{abstract}

\section{RESUMO}

Objetivo: analisar o desenvolvimento do mercado de trabalho na Enfermagem Gerontológica brasileira, entre 1970 e 1996. Método: estudo descritivo-qualitativo, com abordagem histórica, que utiliza a história oral de 14 enfermeiras pesquisadoras atuantes no período histórico, fundamentada nas ideias de Eliot Freidson. Resultados: a Enfermagem venceu barreiras para a transformação das práticas do cuidado ao idoso no período descrito, considerando a inexistência de mercado de trabalho específico; necessidade de conhecimento teórico para o atendimento em Gerontologia; a escassez de pesquisas e pesquisadoras na área; o surgimento do cuidador de idosos; a construção da multidisciplinaridade e a transformação das instituições de longa permanência. Considerações finais: a expansão do mercado de trabalho na época foi fundamentada por avanços na produção do conhecimento sobre o processo de envelhecimento, respaldado pela transição demográfica, que determinou o aumento na demanda de idosos nos serviços de saúde e a promulgação de leis especíicas de proteção aos idosos.

Descritores: História da Enfermagem; Enfermagem Geriátrica; Idoso; Mercado de Trabalho; Geriatria.

\section{RESUMEN}

Objetivo: analizar el desarrollo del mercado de trabajo en la Enfermería Gerontológica brasileña, entre 1970 y 1996. Método: estudio descriptivo-cualitativo, con abordaje histórico, que utiliza la historia oral de 14 enfermeras investigadores y actuantes en el período histórico, fundamentada en las ideas de Eliot Freidson. Resultados: la Enfermería superó barreras para transformar las prácticas del cuidado a los ancianos en el período descrito, considerando la inexistencia del mercado de trabajo específico; la necesidad de conocimiento teórico para la atención en Gerontología; la escasez de investigaciones e investigadores en el área; el surgimiento del cuidador de ancianos; la construcción de la multidisciplinariedad y la transformación de las instituciones de larga permanencia. Consideraciones finales: la expansión del mercado de trabajo en la época fue motivada por avances en la producción del conocimiento sobre el proceso de envejecimiento, respaldado por la transición demográfica, que determinó el aumento en la demanda de ancianos en los servicios de salud y la promulgación de leyes específicas de protección a los ancianos.

Descriptores: Historia de la Enfermería; Enfermería Geriátrica; Ancianos; Mercado de Trabajo; Geriatría. 


\section{INTRODUCTION}

Gerontological Nursing was declared a specialty by the American Nurses Association (ANA) in 1966 ${ }^{(1)}$. In Brazil, studies ${ }^{(2-3)}$ point out that the interest in Gerontology arose as of 1961, with the creation of the Brazilian Society of Geriatrics (Sociedade Brasileira de Geriatria - SBG), which later was renamed the Brazilian Society of Geriatrics and Gerontology (Sociedade Brasileira de Geriatria e Gerontologia - SBGG). In the 1970s, there were advances in the practice and education, when some health services, usually linked to universities, began to offer services to the sick elderly. In the 1980s, these initiatives proliferated and initiated a more systematic care for elderly people, also offering initiatives aimed at health promotion and disease prevention ${ }^{(3)}$.

These advances are based on the progressive increase of the aging index in Brazil, pointed out in recent research, showing that from 1970 to 1980 there was a variation of 30.54\%; from 1980 to $1991,32.26 \%$; from 1991 to $2000,37.42 \%$; and from 2000 to $2010,55.11 \%{ }^{(4)}$. The development of Gerontological Nursing was directly related to the process of demographic and epidemiological transition in Brazil, which resulted in the increase of the elderly population in the country and, consequently, in a growing demand of this population for health services.

Thus, there was a greater concern with this layer of the population, creating new spaces for professional practice, which required qualified training for this service, fostering the construction of knowledge and the consolidation of this Nursing specialty. This finding is in line with the thinking of Eliot Freidson, a sociologist, when he argues that the so-called "consulting" professions offer problem-solving services to lay clients. Therefore, the practical profession has the task of applying knowledge to everyday life and must be, in some way, linked to everyday life and to the common men ${ }^{(5)}$.

In Brazil, Gerontological Nursing was recognized as a specialty in 2001 by the Brazilian Federal Nursing Council (Conselho Federal de Enfermagem - COFEn), by Resolution 260/2001(6). COFEn's backing for the creation of specialties illustrates Eliot Freidson's framework when he says that it is the combination of formal knowledge training and accreditation, which gives professions exclusive access to their market positions. It is precisely this strict control that sustains professional power and privilege ${ }^{(5)}$.

Labor market is pointed out by Freidson as a constituent of professional status by the requirement that only those with occupationally issued credentials that certify their competence can be employed to perform a defined set of tasks. Thus, professionalism represents a method logically distinct from organizing a division of labor. The author expresses a circumstance in which occupations negotiate jurisdictional boundaries among themselves, establish and control their own division of labor ${ }^{(5)}$.

Over the last decades, the labor market in Nursing has shown a substantial growth in the Health sector. This upward perspective has been maintained, since according to the Institute of Applied Economic Research (IPEA) the profession created 27,282 jobs between 2009 and $2012^{(7)}$. On the other hand, a recent survey, published in 2016 on the Brazilian Nursing profile, identifies problems regarding full employability ${ }^{(8)}$. The profession comprises more than $1,800,000$ professionals, out of a total of 3.5 million health workers, representing more than half of all health workers. Nonetheless, this contingent shows signs of employability problems with roughly $5 \%$ of unemployment and $4.5 \%$ of temporary absence. Of the more than 121,000 professionals who reported being unemployed recently, $66.7 \%$ said they had trouble finding a new job.

The quantitative increase of professionals also impacted the development of Gerontological Nursing today, initiating educational initiatives and producing knowledge in the field. The seminars that brought together professionals and students were the driving force behind the creation of the Gerontological Nursing Department (DEGER) at the Brazilian Nursing Association (Associação Brasileira de Enfermagem) in 2009 during the $61^{\text {st }}$ Brazilian Nursing Congress (Congresso Brasileiro de Enfermagem). This department constitutes an important step for the representativeness of this field and for the debate of the training policy within Nursing and public policies of care to elderly people ${ }^{(9)}$.

Considering that, historicizing the construction of the labor market in Gerontological Nursing is needed for a historical re-reading of this specialty and profession, as it brings the components for developing specialized knowledge of the care to elderly people. However, this subject requires a new look, a new perception of research about the profession, referring to the perspective of the specialty of knowledge as an important instrument in the search for professional status.

Historical research significantly contributes to Nursing, seen that it refers professionals to a critical view of the socio-political and cultural aspects that led to their formation. Moreover, it provides the necessary amplitude for the analysis of these factors, revealing the advances achieved in the studied period, as well as the difficulties found. It also encourages reflections on future interventions needed for its professional consolidation.

\section{OBJECTIVE}

To analyze the development of the labor market in Brazilian Gerontological Nursing, between 1970 and 1996.

\section{METHOD}

\section{Ethical aspects}

The research project was evaluated and approved by the Ethics Committee on Research in Human Beings, Pro-Rectory of Research and Extension of the Universidade Federal de Santa Catarina. Participants were clarified about the purpose of research and accepted the Term of Free and Informed Consent and the participation in the interview. All the interviewees abdicated from anonymity because it was a historical-social study, which makes it essential to identify nurse researchers in the study of the aging process in Brazil.

\section{Type of study}

This is a descriptive and qualitative study, with socio-historical approach, that uses the oral history thematic. Oral history deals with the history of the present time and is considered a method of historical, anthropological and sociological research, which 
privileges the performance of interviews, resulting in a source of consultation (interviews) for other studies ${ }^{(10)}$. It uses as theoretical framework the ideas of Eliot Freidson, researcher of the sociology of professions, who sustains the relevance of the labor market to consolidate the professional status, through an exclusive jurisdiction, a monopoly based on qualifying credentials and division of labor controlled by the profession ${ }^{(5)}$.

\section{Methodological procedures}

By looking for the historicity of Gerontological Nursing, the selection of the inclusion criterion of participants fell on the nurse researchers on the study of the aging process, who worked between 1970 and 1996. The delimited period corresponds to the advances of research on elderly people in Brazil, ending with the accomplishment of the I Brazilian Journey in Geriatric and Gerontological Nursing (I Jornada Brasileira de Enfermagem Geriátrica e Gerontológica). This criterion of inclusion delimited, as researchers, the nurses pointed out by their peers in the form of a network, which contributed to the accomplishment of that journey, considered by them as a triggering factor in the socialization of Gerontological Nursing knowledge in Brazil.

To define the sample, the zero interview was carried out, which had as objectives: to validate the interview instrument and to establish a network of relationships to identify nurse researchers in the field, besides contributing to define the temporal space of research. The establishment of the network was aimed at achieving the study objective, according to the guidelines of its own members, excluding the orientation of the authors of this article.

The first contact was made via e-mail, in which the purpose of research was explained, and the invitation was sent for professors, as pioneers on the topic, conferred by their peers. It is hereby recorded the unanimous interest of all the professors contacted, some of whom expressed surprise at being considered pioneers in this field in Brazil.

After this first contact, according to availability of geographic displacement, interviews were scheduled in a private room, chosen by participants. All the interviews had as their stage the institutions of higher education to which professors are linked to or retired from, totaling eight cities and five Brazilian states visited.

\section{Data collection and organization}

Data collection was performed through semi-structured interviews, which occurred from May to November 2009, from a network of relationships initiated at the zero interview and that met the research inclusion criteria.

A total of 14 interviews with nurses indicated by their peers was conducted. These professionals participated since the beginning of Gerontology in the country, contributing to the realization of the $1^{\text {st }}$ Brazilian Journey in Geriatric and Gerontological Nursing, a fact that triggered the socialization of such knowledge in Brazil. Notall the researchers that met the criterion were included in the sample, due to geographic distances, difficulty in contacting and/or scheduling interviews.

For data analysis, the thematic content analysis technique ${ }^{(11)}$ was used, which is the meaning that comes from the text, allowing its interpretation under the approach of the theory that guides the study. The organization of thematic content analysis is unfolded in three steps: pre-analysis; exploitation of the material; and treatment of results, their inference and interpretation. This technique also allows researchers to know a reality through the communication of individuals with whom they have bonds. Two categories of analysis were identified: 1 . The evolution of nursing care practices; and 2 . Constituents of the labor market.

\section{RESULTS}

Analyzing Gerontological Nursing from the perspective of delimitating the labor market is related to the understanding of the construction of the professional practice for this population and how this positioning has been seeking the expansion of action spaces.

\section{The evolution of nursing care practices}

Until the 1960s, the labor market was almost non-existent, according to the report:

In the 1960s, it did not exist. When I entered University, I was through a public test and when they gave me the syllabus of the written test, there was: Gerontological Nursing. There was no book to study for it. I did not know what to do. (Prof. Dr. Clarice de Oliveira)

In chronological order, this speech pointed out that studies on the aging process had a greater impulse as from the 1970s. In the 1980s, the studies of some of the researchers in the field were consolidated, such as those by the professors Lúcia Hisako Takase Gonçalves, Rosalina Partezani Rodrigues, Maria Manuela Rino Mendes, Maria Jalma Santana Duarte and Maria Coeli Campedelli. The data collected allow us to infer that these professors, together with Professor Clarice de Oliveira, can be considered the first generation of nurse researchers in the field.

The interest in the specialty was characterized by the individual interest of these researchers, who, because of their role in teaching or practice of care, experienced antagonistic constituents: the increase the elderly people in health services and the lack of theoretical knowledge to serve this age group.

However, the construction of this labor market faced, from its beginnings, perhaps its greatest difficulty, the perception of care for the elderly people at that time.

No one even mentioned this subject, the aging process was like a frailty matter, near death. It was not a concern. The real concern was much bigger, aimed at diagnosing a disease and its symptoms. (Prof. Dr. Maria Jalma Santana Duarte)

Thus, the first challenge faced by researchers to change the practice in this field was the conviction among their peers that there was a need to study the aging process to care for elderly people. This distancing by nursing professionals provided other actors to care for this population, as it was the case of Bahia State in the 1970s:

Neither was there an auxiliary nurse, nor a nurse, nor a licensed practical nurse. Only a few attendants, [...] but they did not like to care for old people, they were there because they needed to work, to make money. (Prof. Dr. Clarice de Oliveira) 
One of the interviewees seems to give a clue to the explanation of nurses'resistance to make efforts to care for elderly people and, consequently, to the construction of knowledge in this field:

[...], you must work hard. Not to improve the patient's condition, but for it not to get worse. Because if I do not work hard, it will get worse. (Prof. Dr. Aparecida Yoshitome)

However, the interviewees report that implementing theoretical knowledge of elderly care, with a shortage of research and researchers in this field, was an arduous struggle, since the references were mostly international books and articles, not always adequate to the Brazilian reality, which posed even more difficulties:

Then, I saw that many times those guidelines I applied, taken from the books, ipsis litteris, decorated from them, would face a different reality; the patient's wife, daughter, relatives, did everything differently [...] I began to understand that there could be another way. That I was the one who needed to learn to care for them. (Prof. Dr. Célia Caldas)

The work process of nurses, in the 1980s, in nursing homes, required a restructuring:

This is what happened: we, as nurses, had a book in which we wrote down complaints, presented by an elderly patient within 24 hours. Then, when geriatricians arrived, they would check this book, and serve only those patients who had complaints. (Prof. Dr. Tânia Menezes)

Another aspect important for investigation in the analysis of the transformation of the nursing work process was the promulgation of the Brazilian National Policy for Elderly People (Política Nacional do /doso) ${ }^{(12)}$. The interviewees' opinions become convergent regarding the recognition as to rights conquered for the elderly population and as an important instrument to convince their peers. New actor added: the elderly caregiver.

According to the researchers, elderly caregivers were a constant, both as a responsibility of Nursing in the training of human resources and as a threat of labor market invasion:

Nurses were the ones who debated the most, because the mentors of this policy [Brazilian National Policy for Elderly People], who were professionals in the aging process, wanted to embed the issue of lay caregivers as a professional category, as well as the community agents, and not as occupational, which is precisely what they are, and not a professional category. We debated a lot, because it was nothing more than reissuing the role of nursing attendants, something which we were just managing to train and extinguish. (Prof. Dr. Sílvia Azevedo dos Santos).

\section{Constituents of the labor market}

Aiming at a better understanding of the development of the market in Gerontological Nursing in Brazil, research participants were asked about their prospective perception of this construction, allowing to take a glimpse of the advances and limitations found during this path, which would contribute to the future of the field.
For the interviewees, the labor market in Gerontology was expanding decade after decade, concomitant with the increase in the number of elderly people served in the health system. If, in the past, the speeches showed that the convincing power of their peers was needed to highlight the importance of caring for this population, the reality found today is rather different:

I receive demands from institutions asking me for indications of geriatric or gerontological nurses on a weekly basis, [...] then, I see a vast field, with an unoccupied market, in an area where nurses are valued, unlike other areas where these professionals must fight to impose themselves; in this area, you just need to be competent. (Prof. Dr. Célia Caldas)

Among the new spaces of care, conquered over time and cited by the interviewees, there are nursing homes in the private sector and home care, which are market fields occupied by other professionals or lay people. As far as this discussion goes, the interviewees' speeches were unanimous regarding the fact that Nursing does not occupy this space yet.

The lack of interest in the field causes a deficit of professionals in institutions, as well as a devaluation of Nursing work with elderly people:

And one thing that we can see, I take students to practice, we work in nursing homes, and, for students, these are the last places that could be a working place for nurses, [...]. (Prof. Dr. Marilene Rodrigues Portella)

However, the perspective Nursing work in Gerontology, when seen by other professionals and from another point of view, that of entrepreneurship, may bring a renewed guidance:

I currently work with street people. This is a peculiarity of my work. Nurses are the ones who reach these people. [...] So, contact is like a password to have access to their situation. And a very positive password to have access, which I sometimes think we use badly. (Prof. Dr. Ana Cristina Brêtas)

Another constituent of the labor market is the relationship between professionals in the same action space as it is for the Health field. However, the way in which this integration has been developed is a cause for concern among interviewees:

What is the essence of Nursing? If I do not know what the essence of Nursing is, what is my competence as a nurse, how am I going to share it with others? Because I divide it to some extent. I must preserve my competence, my area. [...] (Prof. Dr. Ângela Alvarez)

When asked to comment on the evaluation of the development of Gerontological Nursing in Brazil, the interviewees were unanimous in recognizing that there was a significant growth:

My evaluation is positive. The Journey, which is already in its seventh edition, always has two hundred, three hundred people, which is an expressive number. (Prof. Dr. Rosalina Partezani Rodrigues)

The challenges to be faced from now on must have specialized knowledge as a support, which will allow the claim of exclusive 
competence in nursing care for elderly people. Nonetheless, such knowledge is still being acquired:

[...] many people in this area are nationally recognized as people who produce important knowledge for Nursing. But I would say, such knowledge is still being consolidated, it is not a field yet. (Prof. Dr. Marion Creutzberg)

\section{DISCUSSION}

The speeches illustrate the difficulties found by these researchers. Although Nursing experienced the increasing demand of elderly people in their services, it did not understand that they required specialized care. This practice is currently lived, since a survey on nursing care for elderly patients under the Family Health Strategy ${ }^{(13)}$ found that they are cared for in an unstructured way. Professionals are guided to follow some assistance protocols, but each nurse and team organize the assistance according to their work process, following the dynamics of operation in their units. The authors conclude that the elderly population receives assistance and care for their needs just like users of any age group do, which means they are not cared for according to their peculiarities.

This labor market brought the need for a new systematization, a new look that would later change and consolidate itself in the "gerontological perspective", cited by the researchers interviewed. This is a differentiated look and understanding aging as a stage of the life cycle and perceiving the nuances between senility and senescence.

The search movement for specialized knowledge carried out by researchers agrees with the thinking by Eliot Freidson when affirming that professions called "practices or consultation" must solve the problems presented by their public ${ }^{(14)}$. In this way, professionals must constantly seek scientific knowledge, in order to respond to the expectations and the problem-solving approach expected by society.

Specialization in a given field is inherent in the labor market, since it requires competence or qualifications that only its members have, due to their occupational training, to perform the work in an adequate and reliable manner. It is difficult to sustain a claim of exclusive right to carry out a task that anyone can carry out with equal competence ${ }^{(6)}$. This unique knowledge expertise ultimately determines specializations within professions. A discourse of monopoly of professional knowledge is experienced today by Nursing, which seeks, in scientific knowledge, to delimit its space in the Health field, developing and creating specializations that comprehend the breadth of knowledge.

The speeches given by nurses about untrained professionals who once provided care for elderly people unfortunately do not differ from current data, with similar problems found. Research on nursing care for institutionalized elderly patients indicates that it is of utmost importance to recognize that institutions cannot wok based on hospital dynamics. Because of this misinterpretation, many Long-term Care Institutions for Elderly Patients (Instituições de Longa Permanência para Idosos - ILPI) have turned into poor quality Geriatric Clinics with unskilled professionals, offering palliative care in inappropriate facilities ${ }^{(15)}$.
The qualification deficit shows the lack of training of Health professionals to work within ILPIs, which is a management challenge in Nursing. This lack of preparation of professionals who care for this institutionalized population is clear, both regarding knowledge of the aging process and the recurrent injuries and their repercussions. The challenges pointed out by nurses are related to the aspects of care management, experienced in a solitary way, working with reduced staff, low pay, amidst constant concerns and requirements to qualify teams, in addition to stereotypes perpetuated by society as to the institutionalization of elderly people ${ }^{(16)}$.

Qualifying teams faces the formation of formal caregivers of elderly patients, due to the predominance of short courses, making it impossible to articulate the theoretical-practical process in the teaching-learning process and a discussion about the relational technologies involved in the act of caring. Incomplete secondary schooling makes it difficult to perform activities such as medication administration. However, polypharmacy is a common reality among this population, requiring careful observation of the medication and the dosage administered ${ }^{(17)}$.

Testimonies about caregivers of elderly patients show the concern of the interviewees regarding the labor market. The inclusion of this occupation is currently bringing challenges and frequent discussions, seen Bill 4702/2012, which provides for the exercise of the profession of elder caregivers and provides measures for it ${ }^{(18)}$.

The fragility of the Brazilian nursing political organization creates spaces for to elaborate of public policies that turn precisely against workers. This points to the challenge of building resistance policies by class entities, defending the interests and promoting the technical, scientific, cultural and political development of professionals, exercised by the Brazilian Nursing Association (Associação Brasileira de Enfermagem - ABEn), intensifying the union struggle and strengthening the body of regulation and supervision of this profession.

For Freidson, the occupational control of a division of labor also requires control of its labor market. In a controlled labor market, individual consumers are not allowed to employ whomever they want: they can only choose from the suitably authorized members of the occupation, who have jurisdiction over the tasks to be performed ${ }^{(6)}$. For Nursing to be professionally strengthened, a political mobilization is needed to defend its space in the labor market, establishing private activities for this professional category.

Another constituent in the care practices within Gerontology was multiprofessional work, mentioned by the nurses researched, as an important space to acquire knowledge and improve the labor market. For Freidson, professionalism represents a logically distinct method of organizing a division of labor. It expresses a circumstance in which occupations negotiate jurisdictional boundaries among themselves, establish and control their own division of labor ${ }^{(6)}$

Achieving protection for a strong market requires the creation of horizontal and vertical demarcation frontiers in the face of potential overlap or invasion by contiguous occupations into a division of labor that may not accept exclusion without resistance ${ }^{(6)}$. Thus, reflecting on the delimitations of the activities attributed to each professional category is essential for the labor market of 
Gerontological Nursing. Urgent discussions on the role of Nursing in the multiprofessional team are needed, not only in the care for elderly people, but in all fields of professional activity.

The ease in accessibility of the Nursing/population relationship, provided by the historicity of the profession with care, shows the fact that the category has little tradition of acting as an entrepreneur. Only $1.8 \%$ work in this modality: in cooperative companies $(0.8 \%)$, homecare $(0.5 \%)$ and "other" modalities $(0.5 \%)^{(8)}$. Nursing is a profession of institutionalized activity, in formal employment structures, either public or private. However, when applying new work fields into Long Stay Institutions, day care or home care for the elderly population, would broaden the labor market of this profession.

This perception promotes entrepreneurship, consistent with a liberal profession such as Nursing, when seeking a new working relationship with the population, without employment bonds with the State or institutions. New possibilities of work for Nursing should be the focus of academic and professional debates, because despite the current employability, the perspective is of a significant increase in the supply of new professionals in the market each year. An example of this is the relatively low number of professionals in homecare $(0.5 \%)$, as pointed out by research on the Brazilian Nursing profile, besides being a service delivery modality that brings the reduction of the risks of infection in hospitalization environments, humanization of care in the home environment, reduction of clinical complications and optimization of patient recovery time as benefits ${ }^{(8)}$.

Recognizing the relevance of knowledge to define the labor market is mentioned by the researchers when they demonstrate concerns about the future of the scientific research and the need for compliance of new researchers with the field. This perception finds support in the work of Eliot Freidson work when he emphasizes knowledge as one of the constituents of professional power, capable of subsidizing the delimitations of jurisdictional limits between professions ${ }^{(19)}$.

The prospects are promising, because Gerontology, besides being an emerging specialty in Nursing, is a profitable field of activity. The qualification of elderly care is closely related to the level of knowledge of Nursing professionals, as well as the maintenance of supervision of institutions, postulated by both the public authority and agencies of this class ${ }^{(16,20-21)}$.

Knowledge and autonomy will create places in the labor market, because, as Eliot Freidson affirms, the negotiation of jurisdictional limits between occupations, in order to establish and control the division of labor, expresses the professional power of a category. Thus, Brazilian Nursing, nurses, licensed practical nurses and auxiliary nurses must be alert to the preservation of spaces already conquered and to the delimitation of the specific actions of Nursing within multiprofessional teams to achieve an autonomy in keeping with the aspiration of participants of such specialty.

\section{Study limitations}

It is important to point out that not all the researchers who met the research criteria were included in the sample, due to geographical distances, difficulty of contact and scheduling of interviews. However, they are cited and recognized by their peers as researchers of their time: Prof. Dr. Maria Coeli Campedelli; Prof.
Dr. Maria do Rosário Menezes; Prof. Dr. Maria Manuela Rino; Prof. Dr. Marlene Teda Pelzer; and Prof. Marilene Baquero.

\section{Contributions to the Nursing, Health or Public Policy fields}

Historicizing Nursing specialties is part of the historical re-reading of the profession. It brings the components of the construction of specialized knowledge, initially understood only as a to improve Nursing practice. However, this topic requires a new look, a new perception of research on the profession, when referring to specialized knowledge as an important instrument in the search for professional status. This study brings some contributions to the Brazilian Gerontological Nursing, such as the reporting of its historicity from the point of view of researchers, as well as fostering reflections on future directions towards sociological perspective by bringing the constituents to achieve professional status.

\section{FINAL CONSIDERATIONS}

Concomitant with advances in Gerontology in Brazil, from the 1970s onwards, Nursing care practice in the field was also changed and labor market expanded, which was noted by nurse researchers who lived this prospective and evolutionary movement, when, through motivation and personal resources, they built the fundamentals of the specialty in the country.

Nursing broke down the barriers built for the transformation of care practices: the poor specialized bibliography that led to self-learning; the belief their peers had in the need for specialization in the field, due to differences in care for the adult and elderly populations; the learning process and the construction of multiprofessional work; the contribution to change institutions of long-term stay, seen before as "storage of old people" in spaces of health promotion. Such events occurred due to several factors: the growing production of knowledge of the aging process; the demographic transition that determined the increase in the demand by the elderly population for health services; and the enactment of specific laws protecting them.

However, it is also necessary to highlight the gaps in this labor market that are still a reality despite all collective struggles, health policies and social movements performed over the years. The justifications for these gaps cannot be simplified to single reason. Among them, rationality of healing, strongly rooted within Nursing, as well as stereotype of aging, are some reasons. These constituents are also valid for other professions in Health, which, according to the interviewees, have been positioning themselves in this market. The best explanation may be the perceived employability experienced by the category, even if current data show an increase in unemployment, which would lead to accommodation in terms of gaining new spaces in the labor market.

This perception must be reviewed, as, according to Eliot Freidson, the labor market, that is, the negotiation of jurisdictional limits between occupations, establishing and controlling the division of labor, expresses the professional power of a category. Thus, efforts should be implemented to preserve the spaces already conquered and to delimit the specific actions of Nursing within the multidisciplinary team to reach autonomy in keeping with the aspirations of participants in this specialty. 


\section{REFERENCES}

1. Burnside IM. Enfermagem e os idosos. São Paulo: Organização Andrei; 1979.

2. Neri AL. A pesquisa em gerontologia no Brasil: análise de conteúdos de amostra de pesquisa em psicologia no período de 1975-1996. Texto Contexto Enferm. 1997;6(2):69-105.

3. Santos SSC. Enfermagem gerontológica: reflexão sobre o processo de trabalho. Rev Gaúcha Enferm[Internet]. 2000 [cited 2016 Jul 18];21(2):70-86. Available from: http://seer.ufrgs.br/index.php/RevistaGauchadeEnfermagem/article/view/4318/2279

4. Closs VE, Schwanke CHA. A evolução do índice de envelhecimento no Brasil, nas suas regiões e unidades federativas no período de 1970 a 2010. Rev Bras Geriatr Gerontol. 2012;15(3):443-58. doi: 10.1590/S1809-98232012000300006

5. Freidson E. Professional powers: a study of the institutionalization of formal knowledge. Chicago: The University of Chicago Press; 1986.

6. Conselho Federal de Enfermagem - COFEN. Resolução n 260. Fixa as Especialidades de Enfermagem [Internet]. Brasília; 2001. [cited 2017 Aug. 18]. Available from: http://www.cofen.gov.br/resolucao-cofen-260-2001_66705.html

7. Instituto de Pesquisas Econômicas e Aplicada (IPEA). Ranking traz ocupações com os maiores salários. [Internet]. Brasilia; 2013 [cited 2017 Sep 28]. Available from: http://www.ipea.gov.br/portal/index.php?option=com_content\&view=article\&id=18829

8. Machado MH, Oliveira E, Lemos W, Lacerda WF, Aguiar Filho W, Wermelinger M, et. al. Mercado de trabalho da enfermagem: aspectos gerais. Enferm Foco. 2016;7(ESP):35-62. doi: 10.21675/2357-707X.2016.v7.nESP.691

9. Alvarez AM, Reiners AAO, Polaro SHI, Gonçalves LHT, Caldas CP, Unicovsky MAR. Departamento Científico de Enfermagem Gerontológica da Associação Brasileira de Enfermagem. Rev Bras Enferm. 2013;66(esp):177-81. doi: 10.1590/S0034-71672013000700023.

10. Padilha MI, Bellaguarda MLR, Nelson S, Maia ARC, Costa R. The use of sources in historical research. Texto Contexto Enferm. 2017;26(4):e2760017. doi: 10.1590/0104-07072017002760017

11. Bardin L. Análise de conteúdo. 6ª ed. Lisboa: Edições 70; 2011.

12. Presidência da República (BR). Lei nº 8.842 , de 4 de janeiro de 1994. Dispõe sobre a política nacional do idoso, cria o Conselho Nacional do Idoso e dá outras providências. Brasília; 1994.

13. Resende JO, Silva FMR, Assunção RS, Quadros KAN. Carenurses in the elderly family health strategy. Assistência do enfermeiro ao idoso na estratégia de saúde da família. Rev Enferm Cent O Min [Internet]. 2015 [cited 2016 Jun 28];5(3):183. Available from: http://www.seer.ufsj. edu.br/index.php/recom/article/view/880/935

14. Freidson E. Profissão médica: um estudo de sociologia do conhecimento aplicado. São Paulo: UNESP; 2009.

15. Oliveira B, Concone MHVB, Souza SRP. A Enfermagem dá o tom no atendimento humanizado aos idosos institucionalizados? Rev Kairós [Internet]. 2016 [cited 2017 Jul 27];19(1):239-54. Available from: https://revistas.pucsp.br/kairos/article/view/31112/21529

16. Portella MR, Dias RFR, Dias PS. Desafios e perspectivas da enfermagem gerontológica: o olhar das enfermeiras. RBCEH. 2012;9(2):226-37. doi: 10.5335/rbceh.2012.2282

17. Silva ILS, Machado FCA, Ferreira MAF, Rodrigues MP. Formação profissional de cuidador de idosos atuantes em instituições de longa permanência. Holos. 2015;8(31):342-56. doi: 10.15628/holos.2015.3215

18. Governo Federal (BR). Projeto de Lei n. 4702/12. Dispõe sobre o exercício da profissão de cuidador de pessoa idosa e dá outras providências. Brasília; 2012.

19. Freidson E. Para uma análise comparada das profissões: a institucionalização do discurso e conhecimento formais. Rev Bras Cien Soc. 1996;31:141-54.

20. Kletemberg DF, Padilha MI. Gerontological nursing: the production of knowledge in the profession (1970-1996). Rev Gaúcha Enferm. 2013;34(1):86-93. doi: 10.1590/S1983-14472013000100011

21. Souza EFD, Silva AG, Silva AILF. Active methodologies for graduation in nursing: focus on the health care of older adults. Rev Bras Enferm. 2018;71(Suppl 2):920-4. Available from: http://dx.doi.org/10.1590/0034-7167-2017-0150 